including a $\$ 250$ million arrangement with General Electric to make light bulbs and almost $\$ 400$ million in separate investments by Suzuki, General Motors and Ford to make cars in Hungary - are still going through. PlanEcon Research Associates, a Washington-based consulting company, estimates that Western investment in the Eastern European nations will rise by half this year, to about $\$ 7,800$ million.

But for the most part, the investors are looking at Hungary as a cheap labour pool or as a market. One of the few deals that would have invested in Hungary's hightechnology industry - a plan for Groupe Bull, the French electronics company, jointly to develop and produce consumer electronics in Hungary with Videoton, a large Hungarian telecommunications company - went under when Videoton declared bankruptcy late last year, putting more than 1,000 engineers and techTECHNOLOGY TRANSFER nicians out on the street.

Part of the problem is simple economics: investments in Hungary will generally take years to bear fruit and, as the case of Videoton demonstrates, can be risky. But such chances are not uncommon. What makes Hungary especially difficult for investors now is the still uncertain laws on such basic business issues as environmental responsibility and ownership. Few companies would buy a Hungarian business if they knew that they could be sued for chemical contamination that happened decades ago under a Communist regime. And what happens if someone comes forward and claims that land purchased by a Western investor had belonged to their grandparents before it was nationalized in the 1940s? The law is not yet clear on any of these points. And parliament, with an economic revolution on its hands, is not likely to resolve these issues soon.

\title{
Digging out of the ruins
}

FOR 40 years, being a Hungarian researcher meant a safe job, steady if unspectacular funding, and a captive market for any products one might come up with. That, of course, has all changed, nowhere as much as in the transfer of science to commerce. Where there was once a market within the Soviet bloc for research that was even a decade behind the West, inventions must now compete directly with the rest of the world's.

Despite the reputation of a state owned research enterprise, Hungarian researchers have been doing more over the past four decades than simply holding down their jobs. After all, Hungary's science is the strongest in the region, and applied and technical research is what the country does best, even if not quite as well as the world as a whole (see chart). So last year the government set up an office - known as the Office for International Technology Cooperation (NTEI) - to try to sell, license or find partners for as much domestic science and technology it possibly can.

Last April, NTEI published a booklet entitled Hungarian Ideas Awaiting Foreign Partners that shows just how tough the office's job will be. Of the booklet's 22 technologies, most are agricultural - freeze-resistant yeast, genetic engineering techniques for fish and the like. Hungary has always been something of a breadbasket for the region, and its agricultural innovation may well be excellent. But outside agriculture, the cream of Hungarian technology (at least as offered for sale) gets a bit thin. "Medical check-up of the population" is actually a plea for help in putting together 10 million cheap tests for cholesterol and blood sugar. And the "method for loss- reduction of transmission lines" is really just an advisory committee with a big problem: Hungary needs more power, but anti-nuclear activists will not let it build more nuclear reactors and environmentalists will not let it complete a joint Hungary-Czechoslovakia hydroelectric dam on the Danube. Short of building a conventional power plant that it cannot afford to run, the only solution is to cut electrical losses in the power grid.

This seems to be a common problem with Hungarian technology and technical

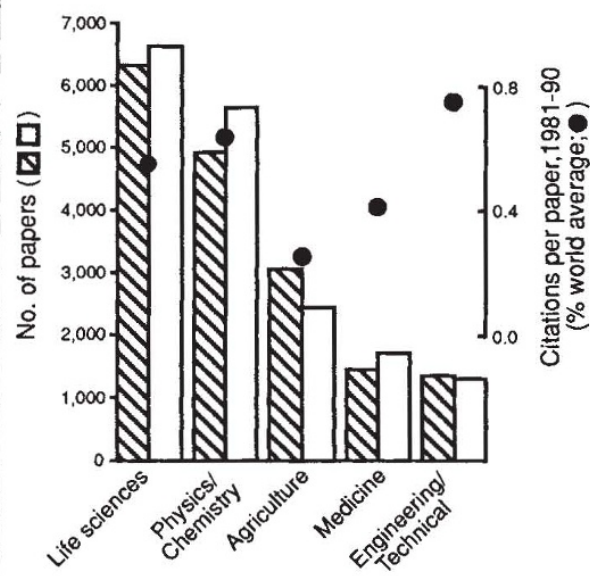

Life-science research is what Hungary does most of, but engineering, technology and applied science is what it does best, according to this study. Although the applied disciplines are a small part of the research enterprise, they appear still to be reaping the rewards of Hungary's traditional strength in physics and chemistry (which, while no longer up to international standards, are still one of the better areas of Hungarian science). Hatched boxes, 1981-85; open boxes, 1985-90.

(Source of figures: ISI science indicators database 1981-90.) opportunities: after 6 months of operation, the new office had yet to make a single sale. Selling businesses is even harder. The State Property Agency has 2,180 state-owned company businesses that it must privatize: by late last year, only two companies had been sold, although others have attracted some foreign investment.

Zsolt Köhalmi, director of NTEI, harbours no illusions about the challenge before him. The ideas, he says, "are not the greatest miracles on Earth, but they're not bad." From a modest twooffice suite on the third floor of an old government office building, Köhalmi is assembling a database of such offerings. He now has a list of more than 1,000 . The problem, he says, is not a lack of Hungarian innovation, but unrealistic expectations from Western investors. "Most of these people discovered Eastern Europe when the Berlin wall came down in 1989 ", he says. They generally come on the expectation that there are some good ideas in Hungary that need developing because of Communist inefficiency, which Köhalmi says is largely true.

"But how fast can you dig something out of the ruins of Communism?" he asks. Because Soviet bloc policies ensured that Hungarian scientists could find a market for almost anything they produced, there was little feedback from customers. Good ideas were often buried in half-baked products. Westernstyle market forces were virtually nonexistent.

So if a Western company does find a Hungarian technology with promise, it should not be surprised to find it a little more rough around the edges than the sort of technology offered by a typical US university. It may have to spend more time developing it into a product, which is inconvenient, Köhalmi concedes. But his prices are low, and he promises that the benefits of a cooperative relationship with Hungarian scientists will pay off eventually.

After an initial surge of interest, however, many prospective buyers seem to be unwilling to cope with the hassle of a cooperative agreement. When US companies do find a Hungarian idea that they think is worth investing in", Köhalmi complains, "they often decide it is cheaper to just use the good old brain drain -- to bring the scientists to the States."

But those investors who do make the extra effort may find payoffs where they least expected them. After all, it was a Hungarian invention that put out many of the oil-well fires after the Gulf War. It may not have been the most hightechnology device - it consisted, in fact, of a pair of jet engines strapped to a tank - but it was quite effective and, somehow, typically Hungarian. 